\title{
Moving Territories: Strategic Selection of Boundary Concepts by Indigenous People in the Bolivian Amazon - an Element of Constitutionality?
}

Helen Gambon \& Stephan Rist, Centre for Development and Environment (CDE), University of Bern This is a post-peer-review, pre-copyedit version of an article published in Human Ecology. The final authenticated version is available online at: $\mathrm{http}: / / d x$. doi.org/10.1007\%2Fs10745-017-9960-z

\begin{abstract}
In this case study, we analyse to what extent the establishment of the Pilón Lajas Indigenous Territory and Biosphere Reserve in the Bolivian Amazon reflects the six elements of the concept of constitutionality. Our analysis elucidates what happened during the second phase of establishment, in which land rights of lowland indigenous peoples were extended to collective territorial rights including highland indigenous peoples and peasants. The case adds a dynamic perspective on the constitutionality framework by providing a longitudinal analysis of a bottom-up institution building process for natural resource governance.
\end{abstract}

\section{Keywords}

Bolivian Amazon. Conservation. Protected areas. Indigenous rights. Collective property rights

\section{Introduction}

The decisions to establish the first protected areas in Bolivia in the 1960s were taken by the national government and local elites without any discussion or consultation with the local populations or a legal framework to coordinate conservation efforts at the national level. The resulting conflict, together with weak implementation, meant that conservation strategies were not very effective (Boillat et al. 2010). In 1992, recognizing the failures of top-down approaches, the government promulgated the law of the "National System of Protected Areas" (Sistema Nacional de Áreas Protegidas, SNAP) (Law No. 1333) that stated that the management of protected areas must be based on the inclusion of local indigenous populations (Alcoba 2004). This reflected the globally shared belief that participation of local people in decision-making processes and engagement in co-management are key for reducing conflicts over resources and increasing efficiency of conservation efforts (McLaughlin 2011; Pimbert and Pretty 1997). 
However, critical reviews of this belief raised questions regarding what forms and under what conditions participation is really effective. Some authors maintain that even if participation is happening and ownership is created, this should be understood as deriving from power exerted through local to national elites (Agrawal 2005; Nadasdy 2005). Others maintain that under certain conditions, bottomup institution building can create genuine ownership, even where quite diverse actors are involved. Haller et al. (2016) offer the concept of constitutionality to examine the conditions under which bottom-up institution building can be successful and define six preconditions for constitutionality processes: 1) local actors (heterogeneous in terms of power, economic assets, age, gender, etc.) perceive a need for new institutions to position themselves in changing contexts; 2) institution-building processes are inclusive and address power asymmetries; 3 ) these processes build upon pre-existing local institutions; 4) outside catalyzing agents provide neutral platforms for negotiations; 5) local knowledge on resources is recognized; and 6) the resulting new institutions are recognized at a higher (national) level.

The constitutionality framework thus emphasizes the views of local actors on participation and the strategies they employ when crafting institutions vis-à-vis comparably more powerful actors. Local actors experience a sense of ownership if economic, political, or social learning benefits are gained in the process. The framework hypothesizes that new institutional arrangements created through such a process are more likely than those resulting from top-down participatory approaches to result in sustainable livelihoods and positive ecological outcomes (Haller 2010; Haller et al. 2016).

In this case study, we analyse how the recognition - firstly of indigenous land rights, and secondly of indigenous territorial rights - operated at the local level of the Pilón Lajas Indigenous Territory and Biosphere Reserve in the Bolivian Amazon. We start with an analysis of the legal provisions on protected areas and indigenous collective land tenure that resulted from strong opposition of indigenous communities in this lowland area, as well as from indigenous organizations of the highlands and valleys of the Andes to existing national policies. This collective resistance by indigenous movements concluded in the creation of nationwide "Indigenous Territories" (Tierras Comunitarias de Origen, TCO), and co-management structures at the local level. We then describe how the creation of "the plurinational state" and the expansion of land rights to territorial rights have challenged locally established institutions, and present an analysis of the implications of the extractive policies of this plurinational state from 2011 onwards, focusing on the state-controlled exploitation of mineral resources, fossil fuels, and hydroelectric energy. We conclude with a discussion of the factors that shape constitutionality processes over longer periods. 


\section{Background}

We selected the Pilón Lajas Indigenous Territory and Biosphere Reserve, located in the Andean foothills of the La Paz and Beni departments and including four municipalities (Rurrenabaque, San Borja, Apolo and Palos Blancos), for the following criteria: a) it is one of the first TCOs created in Bolivia by Supreme Decree in 1992 as a response to the social movements in the 1990s. Collective land tenure of indigenous peoples was formally recognized in 1997 as a TCO, so the local indigenous organization, the Tsimane Mosetene Regional Council (Concejo Regional Tsimane Mosetene, CRTM), had several years of experience in territorial management; b) a system of co-management between the local indigenous organization and the National Service of Protected Areas (Servicio Nacional de Áreas Protegidas, SERNAP) had been created based on a social learning experience that requires ongoing re-negotiation and positioning of indigenous peoples vis-à-vis the state; and c) the TCO is inhabited by three indigenous peoples (Tsimane, Mosetene, and Tacana), who were granted a collective land title by the government. The transition zone of the Biosphere Reserve (BR), beside the Rurrenabaque-Yucumo road that borders Pilón Lajas, is inhabited by indigenous communities of Quechua and Aymara, who migrated to the area from the highlands and valleys since the 1980s and are known locally as "colonos." Pilón Lajas and its influence zone are inhabited by about 9,600 people, of whom about $15 \%(1,400)$ are lowland indigenous peoples who live within the Biosphere Reserve (data from 2004 in Bottazzi 2008). In its own census in 2010, the CRTM recorded a population of about 1,700 persons living in 22 villages (unpublished data provided by the CRTM). About $67 \%$ of the population are Tsimane, $13.4 \%$ Tacana, and 9.4\% Mosetene. The remaining 10.2\% belong to other indigenous groups such as Movima, Esse Ejja, or Lecos, or identify as mestizos. The large majority (96.5\%) of inter-ethnic marriages are within the Tacana communities along the Beni River (SERNAP and CRTM 2009). As with all indigenous nations of the Bolivian lowlands, the indigenous peoples of Pilón Lajas are ethnic minorities. In Bolivia, there are 11,173 Tacana, 6,464 Tsimane, and 1,989 Mosetene (INE 2013) (Fig.1). 


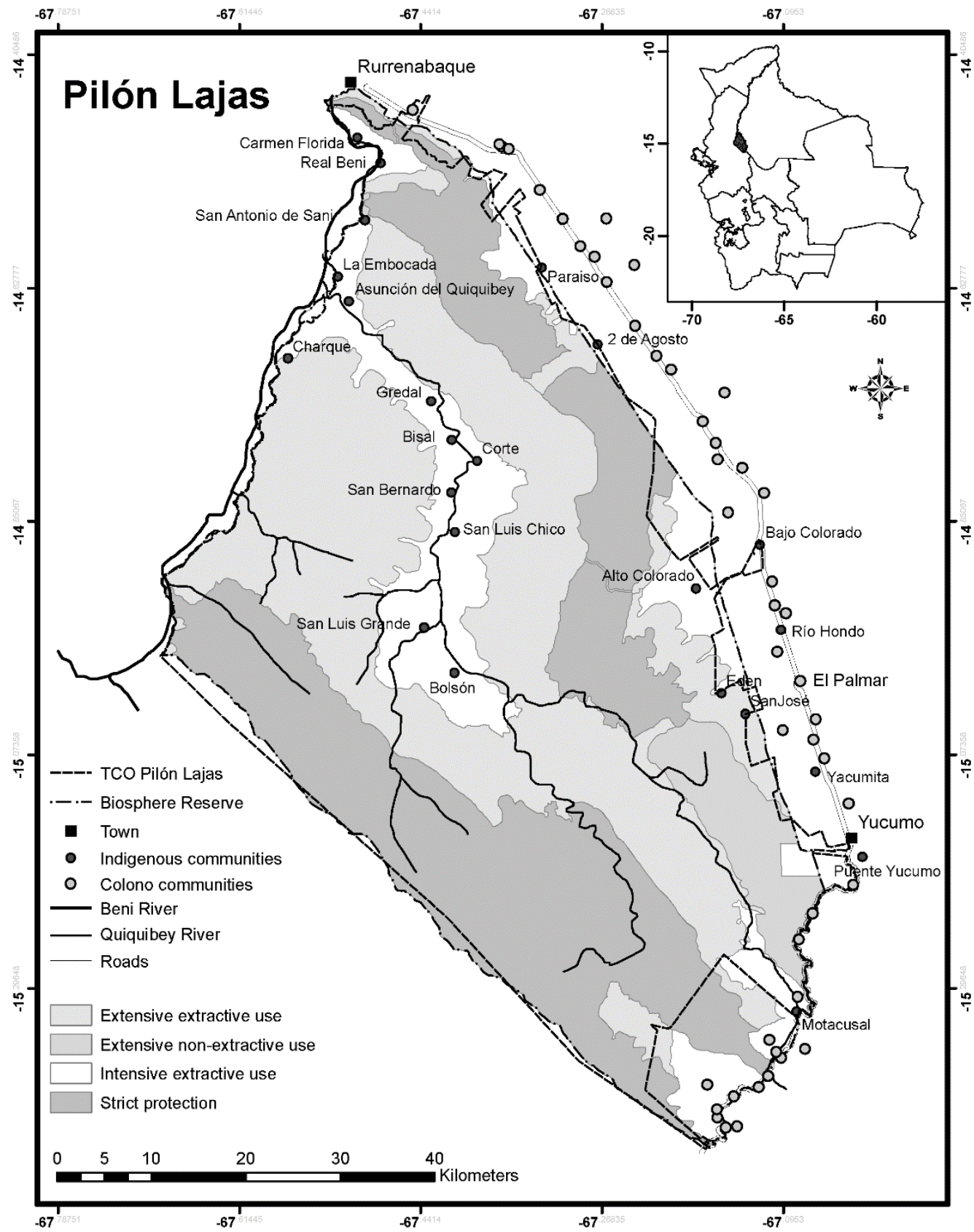

Figure 1: Pilón Lajas Indigenous Territory and Biosphere Reserve

The livelihoods of Tsimane and Mosetene households are largely based on forager-horticulturalist activities with high levels of spatial mobility, while Tacana and colonos base their livelihoods mainly on agriculture (SERNAP and CRTM 2009). Foragers are often more marginalized and less organized than other indigenous groups, making meaningful participation in co-management structures more difficult (Minter et al. 2014). Our case study focuses on the forager-horticulturalist population of Pilón Lajas (Tsimane, Mosetene, and other lowland indigenous inhabitants embedded in Tsimane and Mosetene societies), who represent roughly $77 \%$ of the inhabitants of Pilón Lajas, or $11 \%$ of the total population including the transition zone. 
Mosetene and Tsimane are distinct but closely related ethnic minorities. Men hunt regularly, usually with shotguns or rifles. Fishing techniques (lines with baited hooks, nets, bow and arrow, plant venom) vary according to the water quality and type of water body. Most households breed chickens, and a few families raise pigs. Rice, plantains, manioc, and corn constitute the basic agricultural crops (the average cultivated area is 0.5 ha/household). These activities are predominantly for the subsistence of the family, while occasional surpluses are sold in Rurrenabaque.

The majority of the Mosetene and Tsimane depend on the barter of woven palm leaves used in roof construction (Geonoma deversa) for commodity goods such as cooking oil, sugar, or batteries. Increasingly, men (and a few women) temporarily engage in market-based activities, selling small quantities of timber, or taking occasional paid jobs.

\section{Methods}

The results are based on ethnographic research in Pilón Lajas during 14 months between July 2012 and August 2014. Our base was in Rurrenabaque, a town of about 13,000 inhabitants, where the CRTM and the local office of the SERNAP are located. There, we conducted semi-structured and unstructured interviews (Bernard 2006) with all members of the $\mathrm{CRTM}^{1}$, consultants to the indigenous organization financed by NGOs, the Directors ${ }^{2}$ of the Biosphere Reserve, rangers, and the administrative and planning staff. Main topics of the semi-structured interviews included the institutional history of Pilón Lajas, co-management of the area, and roles of and relationships among actors, while the unstructured interviews provided information on day-to-day operations of institutions and related dynamics. Further, the first author observed the interactions of these actors in the facilities both institutions share in order to assess co-management structures in practice.

The first author undertook regular field trips lasting from 5 to 16 days to the communities along the Quiquibey River. A significant amount of time was spent in two Mosetene-majority communities about 6 hours (Gredal) and 1.5 days (San Luis Grande) ${ }^{3}$ by motorized canoe from Rurrenabaque. Shorter visits were made to seven other Mostene and Tsimane communities along the Quiquibey River (Bolsón, San Luis Chico, San Bernardo, Corte, Bisal, Asunción del Quiquibey) and the Beni River (Charque), as well as one visit to a colono-settlement (El Palmar) along the Rurrenabaque-Yucumo (Fig. 1).

\footnotetext{
${ }^{1}$ The executive committee of the CRTM consists of a President, a Vice-President, and one person responsible for the issues Land and Territory, Health, Education, and Gender.

${ }^{2}$ During the research period, the Biosphere Reserve saw three Directors, of which two were rangers, assuming their position ad interim.

${ }^{3}$ Household and village size vary significantly over time due to the high mobility of residents. During the research period, between 8 and 15 adults lived in Gredal, and between 8 and 12 adults lived in San Luis Grande. 
The main methods we used in the communities were participatory observation (DeWalt and DeWalt 2011; Hammersley and Atkinson 2007) and unstructured interviews (Bernard 2006). The first author engaged actively in the daily activities of various women, men, and children, gaining insights into how people occupy space and interact within and across the territory. Additionally, participatory mapping and transect walks (Chambers 1994) were conducted in both communities, providing information on conceptualizations of space and territory as well as on occupation of space and related knowledge.

\section{Results}

\section{The neoliberal state and the creation of TCOs}

National Bolivian society long considered the forests of the Amazon basin "empty," and indigenous peoples of the Bolivian lowlands were invisible or regarded as marginal (Martinez-Rodriguez 2009). The 1953 Agrarian Reform abolished the feudal hacienda system in the Bolivian valleys and highlands and declared the selvícolas (woodland or jungle dwellers) to be in a "savage state and have a primitive organization" and thus to remain "under the protection of the State" (Decree Law 3464 1953). A government-driven "colonization of the Amazon" by Andean indigenous peoples started in 1980s with the expansion of the agricultural frontier along newly built roads. Indigenous people living in the area for centuries were confronted with the rapid expansion of illegal logging by colonos, and found that the extensive territories needed for their semi-sedentary subsistence were under threat (Bottazzi and Rist 2012). Members of the Guaraní, Ayoreo, Guarayo, and Chiquitano indigenous people started to organize themselves with the support of German anthropologist Jürgen Riester, founding in 1982 the Confederation of Indigenous Peoples of Bolivia (Confederación de Pueblos Indígenas del Oriente Boliviano, CIDOB), an umbrella organization that today represents 34 indigenous peoples (Anthias and Radcliffe 2015; Assies 2006; Hirsch 2003). In March 1990, this new indigenous movement organized the "March for Territory and Dignity" to bring their political agenda to national attention, primarily claiming recognition of their rights and territories. Indigenous organizations from the highlands supported their claims, contributing to the emergence of lowland indigenous peoples as a new social and political force (Assies 2006; Sanchez-Lopez 2015). One year later Bolivia ratified the ILO Convention 169 on Indigenous and Tribal Peoples. This coincided with the political transformation of the country, initiated with a constitutional reform in 1994, recognizing the multi-ethnic and "pluricultural" character of the State and the right of indigenous peoples to their territories, established through the promulgation of Law 1715 (the National Agrarian Reform Institute Law or Ley INRA) in 1996, which introduced the legal category of collective property "Tierras Comunitarias de Origen" (TCOs) (Assies 2006). TCOs are defined as geographic areas that constitute the habitat of indigenous peoples and communities, to which they traditionally have had access, and where they maintain and develop their own ways of economic, 
social, and cultural organization. TCOs establish clear boundaries and are "inalienable, indivisible, irreversible, collective, composed of communities or associations, indefeasible and exempt from the statutes of limitations" (Law No. 1715, Art. 41.I.5). The name indicates that these areas are conceptually based on a notion of land limited to the topsoil: indigenous peoples do not have property rights on water, forest cover, or mineral resources, but "have the right to participate in the sustainable use of renewable resources" (Law No. 1715, Art. 3.III). Today, over 200 TCOs and TIOCs (Territorios Indigena Originario Campesino, see below) exist, spanning over 24 million hectares (56\% is located in the lowlands and $44 \%$ in the highlands and valleys) (INRA 2015). While resulting from demand by indigenous communities in the lowlands (supported by indigenous groups of the highlands and valleys), creation of the legal category of TCOs, and thus of the Pilón Lajas Biosphere Reserve, was a top-down process that originated from the national political elite to resolve its conflict of legitimacy and was rooted in a logic of "multicultural neoliberalism" (González 2010; Van Cott 2001).

The International Union for Conservation of Nature (IUCN) and the World Wildlife Fund (WWF) proposed an area of 280,000 hectares as a national park under the Law on Forest Life, National Parks, Hunting, and Fishing (Decree Law No. 12301) of 1975, as it was judged that its ecosystem had not been sufficiently represented in Bolivia's protected areas network. The local Tsimane were considered an “endangered species" under threat of extinction (Márquez Guerra 2015). Between 1976 and 1977, the Man and Biosphere (MAB) programme designated 118 biosphere reserves across the world in a "fast track" mode. These were areas that had both representative and unique biomes corresponding to the main objective of the MAB programme to "safeguard the genetic diversity of species" (UNESCO 1974: 11). Pilón Lajas, however, remained a paper park, and there was no administration or conservation activity in the years following its creation (Bottazzi 2008; Pauquet 2005).

Following the Indigenous March for Territory and Dignity in 1990, the Bolivian president declared nine "Indigenous Territories" by Supreme Decree ${ }^{4}$, including Pilón Lajas (Assies 2006). This included the recognition that the local Tsimane and Mosetene indigenous population had the right to the "rational use of natural resources" as established by the legislation, and that no new concessions for logging, mining, or oil would be granted. The decree further recognized the area's status as a Biosphere Reserve for the protection of biodiversity and genetic integrity of the flora and fauna (Supreme Decree No. 23110). According to our informants, neither the indigenous population nor their leaders were consulted on the demarcation of the limits of the area (instead, the 400,000 -hectare area defined by the MAB national committee was adopted), nor were they informed or consulted about the creation of the protected area. The state's interests in the natural resources of the area remained high, and after

\footnotetext{
${ }^{4}$ Tsimane, Multiétnico 1, Sirionó, and Isiboro-Securé in 1990, and Weenhayek, Araona, Pilón Lajas, and Yuqui in 1992 (see Law No. 1715 1996). 
creation of the protected area and indigenous territory, it granted concessions to several logging companies, as well as to two oil exploration companies (REPSOL and PETROBRAS) (Laats et al. 2012).

During the first years after creation of the reserve (1993-1998), the French NGO Vétérinaires Sans Frontières (VSF) assumed the management of the area with financial support from the European Union and the Swiss Development and Cooperation Agency. The NGO elaborated a five-year management plan, but as the colonists' interest in participating in the assessments was low, the plan was completed without their involvement. Tensions between the indigenous population, colonos, and the NGO arose as economic development projects carried out by VSF largely benefitted the colonos, while the indigenous population was the target of conservation activities. At the same time, VSF found itself in the crossfire of local elites and colono organizations, as it supported indigenous peoples in expelling logging companies from the Biosphere Reserve. Following escalation of the conflict with the colonos, VSF withdrew in 1996. In 1998, the newly founded National Service for Protected Areas (SERNAP) (Supreme Decree No. 25158) took over the management of the area (Bottazzi 2008; Pauquet 2005), implementing the General Rules for Protected Areas (Supreme Decree No. 24781).

In 1997, the Indigenous Territory became a TCO recognized by the Land Law No. 1715. This title consolidated collective rights of use and access for the Tsimane and Mosetene population in Pilón Lajas, represented by the CRTM. The Tacana, who were not considered by the Supreme Decree in 1992, were recognized as co-owners of the TCO through their affiliation to the CRTM. Access rights of the $10 \%$ of the population that does not belong to any of these three groups were never formally defined. In practice they are tied to social norms concerning marriage and kinship, as well as to natural resource use as defined by informal inter-ethnic institutional arrangements.

The double status of the area as a TCO and Biosphere Reserve resulted in legislative protection of the land (Law No. 1715 ; Law No. 3545) and the environment (Law No. 1333). This suited the interests of both conservationists and indigenous communities, and helped to reduce economic pressure on the natural resources of Pilón Lajas. The large logging concessions were reversed in the late 1990s (Pauquet 2005), while both oil exploration blocks were halted in 2002 and 2004, respectively, for being situated in a protected area. In addition, deforestation within Pilón Lajas due to the rapid expansion of the agricultural frontier was slowed down through the delineation of its boundaries (Bottazzi and Dao 2013; SERNAP and CRTM 2009). The Land Law also recognized the property rights of colonos, who until 1993 had received either individual small properties of 25 hectares, individual medium properties, or collective titles (colonies) as a group (Bottazzi and Rist 2012).

In 2004, a co-management system was negotiated and implemented by the local branch of SERNAP and the CRTM. This collaboration between a government institution and an indigenous organization attracted NGOs and international donors, such as the Department for International Development 
(DFID), USAID, World Bank, Conservation International (CI), Wildlife Conservation Society (WCS), and others, making Pilón Lajas one of the better protected areas in Bolivia (Bottazzi 2008). The legal status of the TCOs in general, and the creation of Pilón Lajas in particular, thus significantly increased state recognition of the indigenous population.

Around the same time, the relationship between the indigenous inhabitants of Pilón Lajas and the colonos living in its transition zone began to deteriorate. In 2005, about 150 people claiming to belong to the Landless Movement (Movimiento Sin Tierra) settled around the Laguna Azul, considered a sacred space by the Mosetene and Tsimane, and started dividing agricultural land into parcels and extracting timber. The indigenous population organized, and with the support of SERNAP expelled the illegal settlers (Fundación Tierra 2010; Surkin et al. 2010). In the same year, the land titling process began, contributing to the intensification of conflict. The process of land registration (saneamiento) was encoded in a law (1715) that combined neoliberal principles (liberalization of the land market) and social justice principles (recognition of indigenous peoples' territorial rights) (Assies 2006) and prioritized third-party claims over the recognition of TCOs (Reyes-García et al. 2014). The land titling process in Pilón Lajas concluded in January 2008 with certification in the name of the CRTM only after 53,874 hectares of the TCO had been allocated as individual titles to colonos settling in the southern part of the area. The boundaries of the TCO and the Biosphere Reserve therefore do not overlap completely (SERNAP and CRTM 2009).

The elaboration of the second management plan, the "Management Plan and Life Plan of the BR-TCO" for the period 2007-2017, was funded and led by WCS whose goal was to develop a document reflecting both conservationist and indigenous views as the basis for the co-management of the area. The indigenous population was thus included at an early stage and more thoroughly than in the first plan, although colonists were not considered stakeholders (Bottazzi 2008; Surkin et al. 2010). In 2010, the CRTM was awarded the Equator Prize of the United Nations Development Programme (UNDP), in recognition of its efforts to reduce poverty through biodiversity conservation, and a Special Recognition for applied indigenous knowledge (UNDP 2012). A Supreme Decree developed by SERNAP in coordination with indigenous organizations from the lowlands and highlands to formalize co-management of protected areas was not however approved by the Cabinet of Ministers (Espinoza T. 2012). Nevertheless, thus far the process corresponds largely to the principles of constitutionality for successful bottom-up institution-building process: a heterogeneous set of local actors calling for new institutions (indigenous territories, co-management structures - element 1 ) that build on traditional institutions for resource governance (common vs. private property - element 3), negotiation of co-management of the area has increased the sense of ownership among lowland indigenous communities (ele- 
ment 2), the NGO WCS served, to a degree, as an outside catalyzing agent (element 4), and the Indigenous Territory has been acknowledged at a higher (national) level through the creation of the TCO, increasing the bargaining power of the indigenous population (element 6). However, both the local (WCS, park authorities) and the national level (legislators) failed to understand indigenous resource governance (element 5 ), and the colonos were excluded from the institution building process (element 2). Nevertheless, most interviewees concur that the double status as protected area and indigenous territory allowed for significantly improved livelihood outcomes and the sustainability of natural resources and the ecosystem.

\section{The "plurinational" state's inter-ethnic focus}

At the national level, the major indigenous and peasant organizations ${ }^{5}$ formed the "Pact of Unity," a political alliance that paved the way for fundamental political changes, such as the election of Evo Morales as the first indigenous president in 2005, the convening of a Constituent Assembly in which the organizations from the Pact of Unity were strongly represented, and the resulting New Political Constitution of 2009 that declared Bolivia a "plurinational" state (Bottazzi and Rist 2012; Fundación Tierra 2010; Schavelzon 2012) and transformed the recognition of the right to land established by the land law in the form of the TCOs into the recognition of the right to a territory by introducing Indigenous Native Peasant Territories (Territorios Indigena Originario Campesino, TIOC) (Garcés 2011). This new legal category is based on a reinterpretation of fragmented rural identities through the introduction of a unifying category of collective citizenship, the indigenous native peasant (Fontana 2014). The change in collective land tenure from TCO to TIOC thus poses new questions of access to and exclusion from territories and natural resources (Bottazzi and Rist 2012; Sanchez-Lopez 2015; Tockman and Cameron 2014).

The constitutional anchoring of the collective tenure category as TIOCs enhances the rights of all the country's indigenous nations to their territories by extending land rights to territorial rights. Wherever TIOCs overlap with protected areas, co-management based on the norms and proceedings of the indigenous peoples should apply (NCPE Art 385.II). The automatic conversion of TCOs to TIOCs was legally established in 2010 (Supreme Decree No. 727).

However, despite this constitutional valorization of plurality, autonomy, and territorial rights of the indigenous population within Bolivian society, the Tsimane, Mosetene, and Tacana of Pilón Lajas vehemently oppose the conversion of their TCO into a TIOC, chiefly because it would reduce the power

\footnotetext{
${ }^{5}$ CIDOB; Unique Confederation of Rural Laborers of Bolivia (CSUTCB); Confederation of Peasant Indigenous Native Women "Bartolina Sisa" (CNCIOB-BS); Syndicalist Confederation of Intercultural Communities of Bolivia (CSCIB); and the Council of Ayllus and Markas of Qullasuyu (CONAMAQ).
} 
of the three groups indigenous to the area relative to the colono organizations of the region. The Aymara and Quechua settlers in the transition zone today outnumber the indigenous population of the whole area by 4 to 1 (Bottazzi 2008, unpublished data provided by CRTM). The colono communities find it unacceptable that roughly 1,700 people possess nearly 400,000 hectares of land, while they have to limit themselves to 25 hectares (or less, due to inheritance rules). The settlers are pushing for the expansion of the agricultural frontier, increasing pressure on indigenous communities, mainly along the road. The indigenous population fears that through the conversion of the status of Pilón Lajas to a TIOC, the colonos along the road could claim access or even property rights based on this title. The Tsimane and Mosetene therefore firmly protect this border.

The rejection of legal permeability does not however extend to practices of social permeability. Our research reveals complex social networks among the inhabitants of Pilón Lajas, other indigenous territories, and the Andean settlers that are not territorially bounded, but extend over the traditionally occupied areas around San Borja, Maniqui River, Alto Beni, and beyond. This is reflected in the longterm movements related to the foundation of the Tsimane and Mosetene settlements in Pilón Lajas (Fig. 2). Tsimane and Mosetene are both semi-nomadic; permanent settlements within Pilón Lajas are relatively new. The oldest current settlements date back to the 1960s, while temporary camps have existed longer.

The TCO Mosetene, contiguous to the southwestern border of Pilón Lajas, and the TCO Tsimane, separated by only $10 \mathrm{~km}$, are both more densely populated than Pilón Lajas ${ }^{6}$. Tsimane and Mosetene from Pilón Lajas all have family members in these areas, and the practice of sóbaqui, i.e., visiting relatives, which is of significant local cultural and economic importance, is common. These visits last between a few days and several months, and usually made to access natural resources or to find spouses (Fig. 3). Spatial mobility is thus used as a strategy to create and maintain kinship relations, friendships, and political alliances. Related to this is flexibility in self-identification in terms of ethnicity according to the social environment in which a person sees him/herself embedded. Statements such as "my father was Tsimane, my mother a Yuracaré, but I am Mosetene" are not unusual. The emic notion of territoriality is hence unbounded and dynamic. Access to and use of natural resources is based on a conceptualization of the environment as constituted of human and non-human communities interconnected through diverse forms of social relationships. Hence, to some elderly Tsimane and Mosetene (particularly women) the notion of a bounded territory remains inconceivable.

\footnotetext{
${ }^{6}$ The TCO's Tsimane and Mosetene both have a population density of about 2 people/km² (Ringhofer 2010; von Stosch 2010), while the population density in Pilón Lajas is about 0.5 people $/ \mathrm{km}^{2}$ (Bottazzi 2008).
} 


\section{Long term movement patterns (years/decades)}
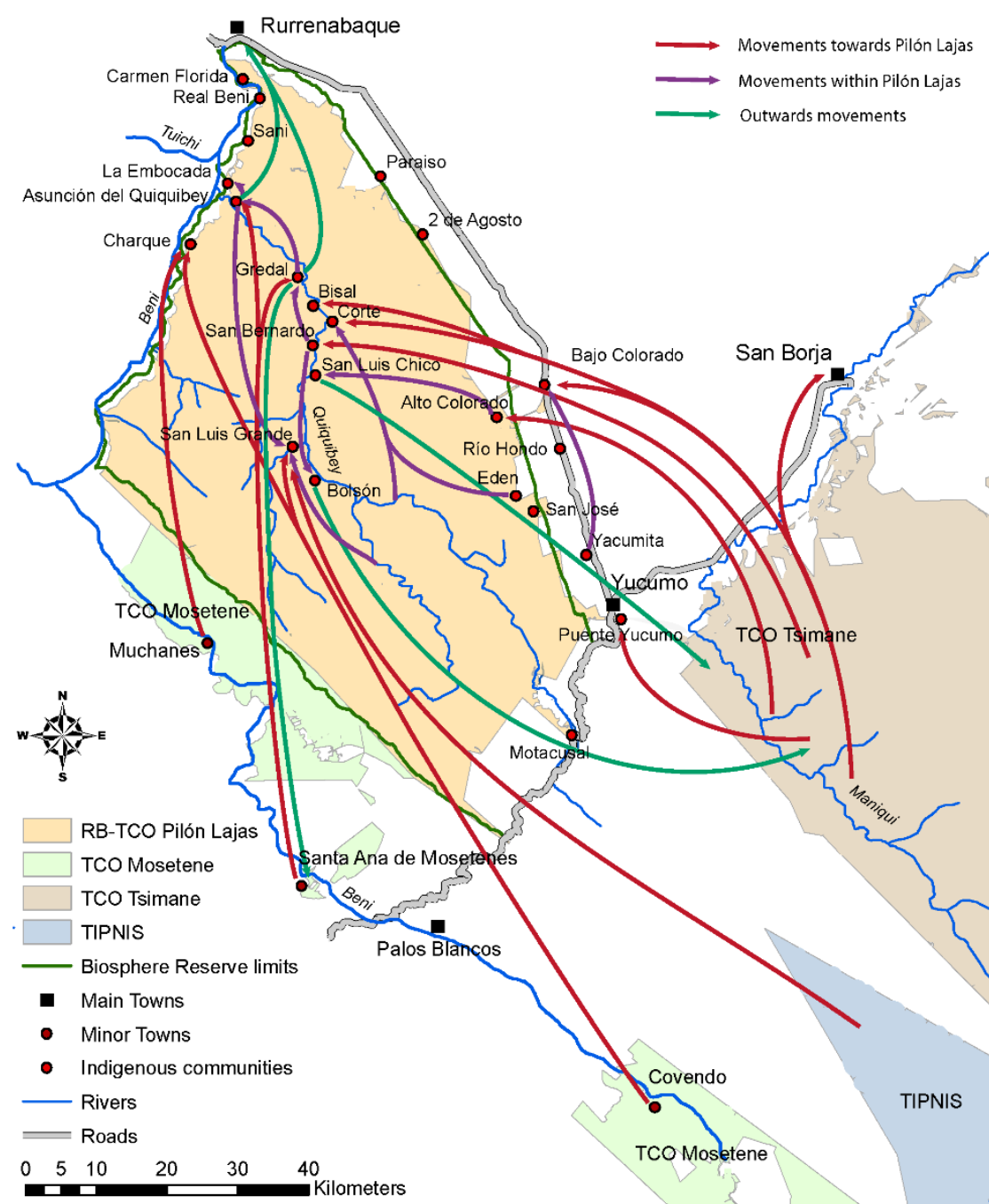

Figure 2: Long term movement patterns (years/decades) within the Tsimane/Mosetene territorial archipelago 


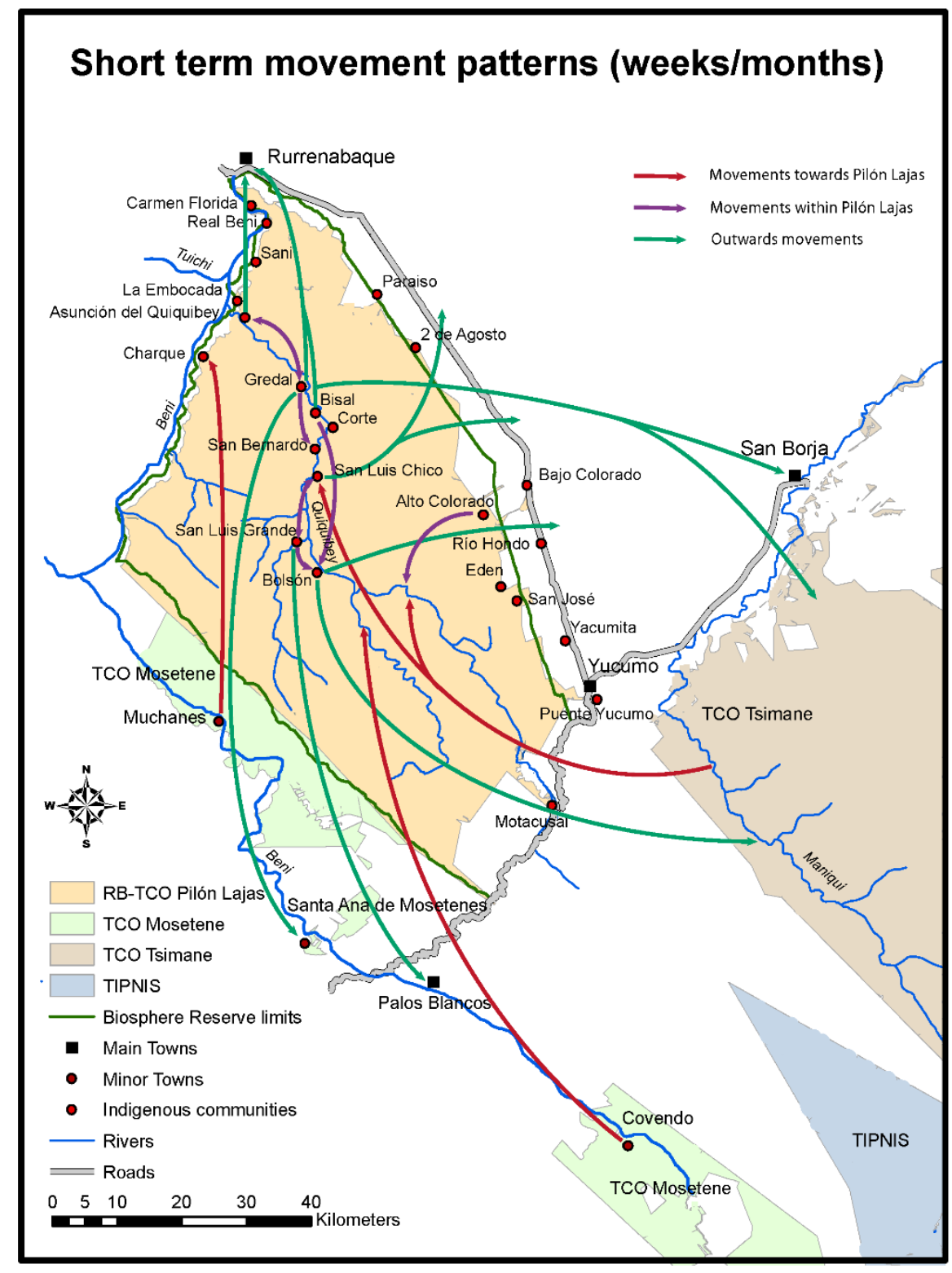

Figure 3: Short-term movement patterns of villagers of the Quiquibey River

However, many families of the TCO Tsimane and TCO Mosetene have shifted their livelihood strategies to logging (Reyes-García et al. 2014; von Stosch 2010; Zycherman 2013), an option that is not viable for the inhabitants of the Pilón Lajas Biosphere Reserve, which limits the possibilities for commercial extraction of timber. Hence, the abundance of and dependency on game and fish in these TCOs is lower than in Pilón Lajas. Tsimane and Mosetene from the Maniqui and Alto Beni regions visiting relatives in Pilón Lajas have the right to access natural resources. Locals often complain that their visiting relatives from outside the TCO hunt and fish excessively, and hence disturb the relationship with the Owner spirits of the animals and the fish. While some residents denounce excessive resource use at the CRTM and SERNAP, generally no sanctions are enforced. Most people expect the Owner spirits to punish infringers of hunting and fishing rules. Although the natural resource base in Pilón Lajas is cur- 
rently healthy, some interviewees were afraid that these dynamics, combined with the ongoing pressure from settlers, might lead to overexploitation such as they experienced in the past in their areas of origin. We therefore conclude that in the emic notion of Tsimane and Mosetene in Pilón Lajas governance, rather than being defined by legal categories (as is the case for the state and peasants) is determined by customs and beliefs that regulate interactions among human societies as well as among human and non-human societies, such as Owner spirits.

Another dynamic arises from the expansion of intermarriage between the Tsimane communities along the road and colonos, transforming the social institutions that define access to common pool resources for local actors. Inter-ethnic marriages are not only frequent among lowland indigenous peoples but increasingly frequent among lowland and highland indigenous populations. Marriage, like kinship, provides access to the common property resources of Pilón Lajas. Both men and women related to Mosetene or Tsimane through marriage along the Quiquibey River have integrated themselves into the way of life of the local communities, following customary norms on resource use and social relationships. However, male settlers along the road who marry women from Tsimane families but nonetheless maintain close relationships with their relatives of Aymara or Quechua origin often continue using the land according to settler traditions. As their livelihood strategy remains based mainly on agriculture, this means they clear on average more forest for permanent plots - up to 5 hectares - than the Tsimane families clear under the shifting cultivation ( 0.5 to 1 hectare). Inter-ethnic marriages also allow Tsimane to gain access to agricultural lands beyond the TCO that are part of the land market. Related to this process, we observed that Tsimane communities along the road, although situated within the TCO, have begun to treat land as private property (Bottazzi 2009). Some communities intend to create communal territories in order to exclude the other members of the TCO from what is supposedly "their" land. In this context, clearly defined boundaries have extended from the TCO to the community to the individual plot, changing land use patterns considerably along the road, and highlighting the profound transformations Tsimane society is undergoing.

The TCO introduced and legally defined borders that from an emic perspective and in social practice are permeable. Thus the TIOCs, designed to overcome social fragmentation based on ethnicity, seem to better match the social reality of indigenous peoples in Bolivia. However, the lowland indigenous communities perceive the TIOCs as undermining their bargaining power vis-à-vis highland colonos in determining their way of life and related land use. Consequently, conditions for a constitutionality process have in this case been reduced significantly by the introduction of a tenure category aimed at a better conceptualization of indigenous practices. The former mismatch between legal delineations and social permeability of the TCOs thus disappeared as borders became important for political rea- 
sons and clearly defined boundaries became acceptable to maintain the internal function of social permeability. In this sense, despite violating local notions of permeability, the TCO became a political advantage for Tsimane and Mosetene.

\section{The shift to a neo-extractivist focus}

In December 2011 the indigenous organizations CIDOB and CONAMAQ withdrew from the "Pact of Unity" as a result of the controversy surrounding a planned road through the Indigenous Territory and National Park Isiboro Securé (TIPNIS). The remaining three peasant and colono organizations reinforced their alignment with the Morales government over this conflict (Rojas M. 2011). Numerous inhabitants of Pilón Lajas joined the "IX Indigenous March in Defense of the TIPNIS" to La Paz to defend the constitutional rights of lowland indigenous peoples against the neo-extractivist agenda of the government. The TIPNIS case illustrates the plural conceptions of development and well-being in the "new" Bolivia of Morales, which is based on the extraction of non-renewable resources and energy production for export (Agenda Patriótica 2025 2013). The revenues are used primarily to finance three social cash-transfer programs ${ }^{7}$ (Fontana 2013b). Pilón Lajas is one of seven areas that the government opened up for fossil fuel exploration and exploitation (Imaña 2015). In addition, it has reactivated as a national priority (Supreme Decree No. 29191), an old proposal for a hydroelectric plant on the Beni River ("El Bala") that was highly criticized by indigenous peoples and conservationists, as it would entail the flooding of the major part of Pilón Lajas and a significant area of the Madidi National Park (Geodata 2016) ${ }^{8}$.

Further, colono organizations as well as the agri-business are now allying themselves with the government to expand the agricultural frontier. The 2015 national agricultural summit tripled the agricultural and livestock economy of the country, including the extension of the area permitted for smallholder deforestation from 5 to 20 hectares (La Razón "Sobre Normativa Agropecuaria" 2015; Paz Ballivián 2015). This increases pressure on protected areas and the TCOs of lowland indigenous communities, which are framed as the "new latifundios" by the peasant organizations (Sanchez-Lopez 2015). ${ }^{9}$

\footnotetext{
${ }^{7}$ Bono Juancito Pinto (incentive for school attendance), Bono Juana Azurduy (support to new mothers), and Renta Dignidad (universal pension fund).

${ }^{8}$ Based on a feasibility study conducted by the Italian company Geodata in 2016, the project was recently adapted to consist of two dams, the Chepite and El Bala. The El Bala artificial lake would, at full capacity, flood an area of 9300 hectares, of which roughly 4800 hectares would directly affect Pilón Lajas (Geodata 2016).

${ }^{9}$ Indeed, lowland indigenous peoples, representing roughly $5 \%$ of the national population, claim $21 \%$ of the national area as indigenous territories (Fundación Tierra 2011; INE 2013). However, it should be noted that lowland indigenous peoples' lifestyles that are based on hunting and shifting cultivation that require larger areas with little human encroachment.
} 
In addition, the regional road infrastructure program IIRSA (Initiative for the Integration of the Regional Infrastructure of South America) is expected to increase migration into the buffer area of Pilón Lajas, as the road flanking the area is part of the "Northern Corridor" linking Bolivia with Peru and Brazil (Laats et al. 2012). In 2011, negotiations began with the Bolivian Road Administration and the InterAmerican Development Bank but were put on hold due to CRTM's participation in the IX Indigenous March. By 2013, negotiations appeared to be successful, and CRTM was promised compensation of USD 300,000. The CRTM and the assembly of Corregidores decided to invest this money in $40 \mathrm{~km}$ of fences along the territory borders that are particularly contested, as well as in training and equipping "territorial guards" (CRTM 2011-2013 2013). However, neither the actual construction of the fences nor the recruitment of territorial guards has begun, as there are disagreements between the CRTM and the government on financial management aspects of the project.

Another direct consequence of external pressures related to government-driven development plans was the replacement of the political representatives of the CRTM in 2015. While the "river communities" and the former CRTM representatives chose open opposition towards the government, the "road communities," a majority, favored a cooperative approach and initiated replacement of all members of the CRTM. It is probable that CRTM representation will oscillate between opposition and pro-government factions, depending on internal and external dynamics.

While in 2005 the relationship of the indigenous population with the state helped the inhabitants of Pilón Lajas to defend their interests, ten years later the situation has changed. From the CRTM's perspective, the major threats to the integrity of their territory and hence to the livelihoods of Tsimane, Mosetene, and Tacana now come from the state and SERNAP is no longer considered a reliable partner. The Biosphere Reserve authorities and rangers find themselves unable to support actions against the government's development plan, despite their concerns about possible impacts of oil exploitation or the hydroelectric dam, for fear of losing their jobs. The Bolivian government has established its political legitimacy and moral authority by “speaking like an indigenous state" (Zimmerer 2013). However, it has not yet overcome the discrepancy between the growth-driven neo-extractivist approach of the Patriotic Agenda, and the indigenous rights and decolonization discourse embodied, for example, in the Law of Mother Earth and Integral Development to Live Well (Law No. 300) (Artaraz and Calestani 2015; Fontana 2013a; Zimmerer 2015).

The concept of ownership developed by the indigenous communities at the beginning of the constitutionality process will not automatically remain stable over longer time periods due to various factors including changes in their emic perception of territory in their worldview, changes in the political power relations among different indigenous actors, or changes in the relative importance accorded a protected area in government development agendas. 


\section{Discussion}

The strong social movements of the indigenous communities of Bolivia initially successfully challenged the top-down governance of natural resources promoted by the government's neoliberal policies causing a significant increase in the state recognition of indigenous rights, and hence their bargaining power vis-à-vis the state, culminating in the creation of TCOs. Although the establishment of the TCO in Pilón Lajas was a top-down process, it offered opportunities for its inhabitants to participate in its management. The CRTM, representing the interests of the indigenous Tsimane, Mosetene, and Tacana, allied with the local SERNAP over common goals, notably keeping loggers, oil companies, and colonos out of the area. This collaboration eventually led to the creation of a co-management system that increased the sense of ownership of the indigenous populations in the institution-building process, particularly of those involved in the CRTM, the SERNAP (as indigenous rangers), and collective actions. Nevertheless, resource governance in Pilón Lajas is shaped by formal state institutions (TCO, Biosphere Reserve) that represent notions of governance that do not correspond to the lowland indigenous concepts of a permeable and changing territory. The legal categories introduced by the neoliberal state were based on a delineation of borders and rules concerning resource use formulated on scientific assumptions of ecosystem management (Muller 2014; Umans and Arce 2014).

Our case study shows that where top-down institutional arrangements do not fully fit local realities, people develop hybrid forms of formal and informal institutions to dynamically regulate the access to territory and natural resources (Bennett and Sierra 2014; Bollig and Menestrey Schwieger 2014; Cleaver and de Koning 2016; Gombay 2014). People affected by processes such as the creation of the TCO or by the top-down Biosphere Reserve in Pilón Lajas were not just recipients of new institutional arrangements, but attempted to define them according to their own world view. The spatial delineation approach of the INRA law separated territorial from social contexts, while the Biosphere Reserve separated economic from socio-cultural and local institutional contexts. The TCOs thus resulted in highly fragmented entities (see also Anthias and Radcliffe 2015; Reyes-García et al. 2014; Umans and Arce 2014). Reyes-García et al. (2014) suggest that the recognition of indigenous land claims has led to archipelagos of territories. Apart from private lands, indigenous communities in Bolivia are now distributed across different TCOs: the Tsimane currently over four, the Mosetene over two, and the Tacana over five, of which only Pilón Lajas is uninterrupted. In practice, access to natural resources is not created through membership of a TCO, but through kinship and marriage. Through the social institution of sóbaqui, the bounded territory of Pilón Lajas is extended and interconnected with the TCOs of Tsimane and Mosetene as well as with non-indigenous communities and towns (Figs. 2 and 3). 
By maintaining links between the territorial archipelagos created by the tenure formalization process, the inhabitants treated the clearly delineated borders of Pilón Lajas as flexible and dynamics. The indigenous population recognized the value of the protected area to defend their territorial claims against further fragmentation and commercial interests (West et al. 2006). Top-down governance can thus in certain cases be important for enhancing bargaining power of the local population when relative values are changing.

However, power asymmetries may become irreconcilable if interests in an area and its natural resources and development potential are shifting. In Bolivia, the relationship of the state with indigenous peoples has evolved considerably over the last two decades. The unambiguous recognition of indigenous rights and principles after the election of President Morales, endorsed in the New Political Constitution of 2009, led to an unprecedented alliance between the state and indigenous and peasant organizations that at first positively influenced constitutionality processes in Pilón Lajas: territorial rights were formally recognized through a collective land title, inhabitants started to develop a sense of ownership in relation to particular collective action, and co-management with SERNAP led to an improved natural resource base.

However, other, more powerful, actors such as the colonos also built strategic alliances with the state. The comparative advantage of the indigenous partnership with the state started to shift when the government began to prioritize national economic and social development over specific priorities of indigenous communities. The introduction of the TIOCs marked an expanded constitutionality process at the national level, as it incorporated perspectives and needs of the highland and valley indigenous populations, focusing on inter-ethnic rights. The related territorial permeability seems to better fit indigenous notions of spatial governance. However, since the colonos and coca-growing peasants are the strongest constituency within the governing Movement Toward Socialism party (MAS), the TIOCs not only strengthen their land claims, but also allow the state to expand its influence in the areas that were under the sovereignty of lowland indigenous peoples (Sanchez-Lopez 2015). The state's interest in Pilón Lajas and its buffer zone for energy production and infrastructure projects changed relative land values of the area to a degree that the bargaining power of the CRTM dropped significantly. Hence, the indigenous populations have lost their once most important ally, the state. The government's shift from a top-down driven development approach to neo-extractivist policies is perceived by the Mosetene and Tsimane as undermining their right to self-determination as established by the Constitution, and lowering their bargaining power to define their own development vis-à-vis the state and the colonos. Against this background, the clearly delineated boundaries of the TCO became a useful tool to protect indigenous priorities. Another strategy, chosen by the majority of the Tsimane road 
communities, is an attempt to recreate the alliance with the state and colonos in order to regain their bargaining power.

\section{Conclusion}

Our case study of the Indigenous Territory and Biosphere Reserve Pilón Lajas shows that the elements of constitutionality defining bottom-up institution-building processes for natural resource governance are dynamic and thus positive outcomes cannot be assumed to persist once successful new institutions are agreed upon, but instead require constant re-negotiation among all parties. In this particular case, we analyzed two factors that contributed to potentially unsustainable outcomes over longer periods of time.

We show that it is pivotal for emerging constitutionality processes that governance frameworks take into account emic human-nature relationships (Blaser 2009; Muller 2014). In this case, the wide range of notions regarding territorial occupation, development, and conservation of the impacted actors were not sufficiently incorporated into the institution-building process. As a consequence, not all developed a sense of ownership of the co-management structures that is a necessary condition for development of successful institutions. In settings where the actors are particularly heterogeneous, e.g., different indigenous populations, colonos, state actors, and conservationists, a special focus is required on how the involved actors perceive their environment and their position within it in order that these more fundamental perspectives are reflected in territorial dynamics and related forms of territorial occupation and use of natural resources. The mismatch between external and internal conceptualizations of governance - and the missing platform for exchange to bring together different worldviews shaping resource governance - challenges the success of an initially promising constitutionality process in Pilón Lajas (Rathwell et al. 2015; Tengö et al. 2014).

Our analysis also shows that although recognition of the new institutions by the state is a prerequisite for constitutionality processes to proceed, it may also become a factor contributing to the dissolution of the new institutional settings if these processes are co-opted by the state to advance interests incompatible with the original objectives that informed the institution-building process. Within the neoliberal state, the TCO served to defend indigenous rights against expansion of the agricultural frontier and commercial interests. Since the "plurinational" state under the MAS government itself claims to be 'indigenous' (Canessa 2014; Sanchez-Lopez 2015), the boundary of identity, and hence the grounds for articulation of claims to specific rights, dissolves. The struggle is no longer one of "indigenous peoples" versus "the state," but rather revolves around discourses of the collective indigenous native peasant citizen and related politics of resource extraction for the well-being of Bolivia's majority on the one hand, and the protection of cultural diversity and marginal peoples on the other (Canessa 2014; Fontana 2013a, 2014). 
In this changing context, the inhabitants of Pilón Lajas first employed defensive strategies such as clear opposition towards the state and increased delineation of borders. Recognizing the comparative advantage of participation in institution-building processes, based on their experience of co-management of the area, the lowland indigenous peoples of Pilón Lajas have decided to again seek alliance with the state and colonos in order to participate in the next round of negotiations concerning the governance of natural resources in the area they share.

\section{Acknowledgments}

The authors thank Jill Belsky and four anonymous reviewers for their valuable comments on the draft of the article, and Darcy Alexandra and Tina Hirschbuehl for language editing.

\section{Compliance with Ethical Standards}

All actors involved in this research were informed about the aims of the study in a comprehensible manner; their decision to participate or not was respected throughout the research period.

Conflicts of interest: The authors declare that there are no conflicts of interest to disclose. 


\section{References}

Agenda Patriótica 2025. 2013. Government of the Plurinational State of Bolivia. http://comunicacion.presidencia.gob.bo/docprensa/pdf/20130123-11-36-55.pdf.

Agrawal, Arun. 2005. Environmentality. Technologies of Government and the Making of Subjects. Edited by Rocheleau Arturo Escobar, Dianne, New Ecologies for the Twenty-First Century. Durham: Duke University Press.

Alcoba, Juan Rene. 2004. Marco institucional y estratégico del Sistema Nacional de Áreas Protegidas de Bolivia (SNAP). In Freddy Delgado B., Mariscal C., Juan Carlos, ed., Gobernabilidad social de las áreas protegidas y biodiversidad en Bolivia y Latinoamérica, 163-77. La Paz: Plural editores.

Anthias, Penelope, and Sarah A. Radcliffe. 2015. The ethno-environmental fix and its limits: Indigenous land titling and the production of not-quite-liberal natures in Bolivia. Geoforum 64:257-69.

Artaraz, Kepa, and Melania Calestani. 2015. Suma qamaña in Bolivia. Indigenous Understandings of Well-Being and Their Contribution to a Post-Neoliberal Paradigm. Latin American Perspectives 42 (204):216-33.

Assies, Willem. 2006. Land tenure legislation in a pluri-cultural and multi-ethnic Society: The case of Bolivia. Journal of Peasant Studies 33 (4):569-611.

Bennett, Drew E., and Rodrigo Sierra. 2014. Multi-Scale Dimensions of Indigenous Land Tenure in the Amazon. Human Ecology 42 (4):551-63.

Bernard, Harvey Russell. 2006. Research Methods in Anthropology. Qualitative and Quantitative Approaches. Lanham: AltaMira Press.

Blaser, Mario. 2009. The Threat of the Yrmo: The Political Ontology of a Sustainable Hunting Program. American Anthropologist 111:10-20.

Boillat, S., J. Alca Castillo, A. Álvarez, Bottazzi P., D. Ponce Camacho, E. Serrano, V. Biffi, SL. MathezStiefel, PB. Larsen, and S. Rist. 2010. Protected areas and indigenous peoples in Bolivia and Peru: Dilemmas, conflicts, and ways out. In H. Hurni, U. Wiesmann and (with an international group of co-editors), eds., Global Change and Sustainable Development: A Synthesis of Regional Experiences from Research Partnerships, 501-15. Berne: Geographica Bernensia. University of Bern. Switzerland.

Bollig, Michael, and Diego A. Menestrey Schwieger. 2014. Fragmentation, Cooperation and Power: Institutional Dynamics in Natural Resource Governance in North-Western Namibia. Human Ecology 42:167-81.

Bottazzi, Patrick. 2008. Linking "Socio-" and "Bio-"Diversity : The Stakes of Indigenous and Nonindigenous Co-management in the Bolivian Lowlands. In Tobias Haller and Marc Galvin, eds., People, protected areas and global change. Participatory conservation in Latin America, Africa, Asia and Europe, 81-109. Bern: Geographica Bernensia.

Bottazzi, Patrick. 2009. Aux frontières des «ordres» institutionnels territoriaux Peuples autochtones, aires protégées et colonisation agricole en Amazonie bolivienne.

Bottazzi, Patrick, and Hy Dao. 2013. On the road through the Bolivian Amazon: A multi-level land governance analysis of deforestation. Land Use Policy 30 (1):137-46.

Bottazzi, Patrick, and Stephan Rist. 2012. Changing Land Rights Means Changing Society: The Sociopolitical Effects of Agrarian Reforms under the Government of Evo Morales. Journal of Agrarian Change 12 (4):528-51.

Canessa, Andrew. 2014. Conflict, claim and contradiction in the new "indigenous" state of Bolivia. Critique Of Anthropology 34 (2):153-73.

Chambers, Robert. 1994. Participatory Rural Appraisal (PRA): Analysis of Experience. World Development 22 (9):1253-68.

Cleaver, Frances, and Jessica de Koning. 2016. Furthering critical insititutionalism. International Journal of the Commons 9 (1):1-18. 
CRTM, Concejo Regional Tsimane Mosetene. 2011-2013. Libro de Actas 2. Rurrenabaque: unpublished.

CRTM, Concejo Regional Tsimane Mosetene. 2013. Libro de Actas 3. Rurrenabaque: unpublished.

Decree Law 3464. 1953. Government of the Republic of Bolivia. http://www.lexivox.org/norms/BODL-19530802.xhtml.

Decree Law No. 12301. 1975. Government of the Republic of Bolivia. http://www.fao.org/faolex/results/details/en/?details=LEX-FAOC026683.

DeWalt, Kathleen Musante, and Billie R. DeWalt. 2011. Participant observation: a guide for fieldworkers. Lanhman and Plymouth: AltaMira Press.

Espinoza T., Carlos W. 2012. La Participación Social en la Gestión de las Áreas Protegidas. Experiencias de la Cooperación Alemana. La Paz: SERNAP, Cooperación Alemana.

Fontana, Lorenza. 2013a. Evo Morales at the crossroads: problematizing the relationship between the state and indigenous movements in Bolivia. Iberoamericana. Nordic Journal of Latin American and Caribbean Studies 18 (1-2):19-45.

Fontana, Lorenza. 2013b. On the Perils and Potentialities of Revolution. Conflict and Collective Action in Contemporary Bolivia. Latin American Perspectives 40 (190):26-42.

Fontana, Lorenza. 2014. The 'indigenous native peasant' trinity: imagining a plurinational community in Evo Morales's Bolivia. Environment And Planning D-Society \& Space 32:518-34.

Fundación Tierra. 2010. Reconfigurando territorios. Reforma agraria, control territorial y gobiernos indígenas en Bolivia. La Paz: Fundacion Tierra.

Fundación Tierra. 2011. Territorios Indígena Originario Campesinos en Bolivia. Entre la Loma Santa y la Pachamama. La Paz.

Garcés, Fernando. 2011. The Domestication of Indigenous Autonomy in Bolivia. From the Pact of Unity to the New Constitution. In Nicole Fabricant and Bret Gustafson, eds., Remapping of Bolivia. Resources, Territory, and Indigeneity in a Plurinational State. Santa Fe: School for Advanced Research Press.

Geodata. 2016. Ficha Ambiental. Estudio de identificación proyecto hidroeléctrico El Bala "Componente 2 Angosto El Bala 220". Cochabamba: ENDE.

Gombay, Nicole. 2014. 'Poaching' - What's in a name? Debates about law, property, and protection in the context of settler colonialism. Geoforum 55:1-12.

González, Miguel. 2010. Autonomías Territoriales Indígenas Y Regímenes Autonómicos (Desde El Estado) En América Latina. In Miguel González, Araceli Burguete Cal y Mayor and Pablo OrtizT., eds., La Autonomía a Debate. Autogobierno Indígena Y Estado Plurinacional En América Latina. Quito, Ecuador: FLACSO, GTZ, IWGIA, CIESAS, UNICH.

Haller, Tobias. 2010. Disputing the Floodplains: Institutional Change and the Politics of Resource Management in African Wetlands (With a foreword by Elinor Ostrom), African Social Studies Series. Leiden: Brill.

Haller, Tobias, Greg Acciaioli, and Stephan Rist. 2016. Constitutionality: Conditions for Crafting Local Ownership of Institution-Building Processes. Society \& Natural Resources 29 (1):68-87.

Hammersley, Martyn, and Paul Atkinson. 2007. Ethnography: Principles in Practice. Abingdon, New York: Routledge.

Hirsch, Silvia María. 2003. The Emergence of Political Organizations among the Guaraní Indians of Bolivia and Argentina: A Comparative Perspective. In Erick D. Langer and Elena Muñoz, eds., Contemporary Indigenous Movements in Latin America. Wilmington, Delaware: Scholarly Resources Inc.

Imaña, Gabriela. 2015. "Petroleras Ingresarán a 7 Áreas Protegidas Hasta 2016." La Razón, June 14. http://www.la-razon.com/suplementos/financiero/Petroleras-ingresaran-areas-protegidasfinanciero 0 2288171307.html.

INE. 2013. Principales Resultados del Censo Nacional de Poblacion y Vivienda 2012 Estado Plurinacional de Bolivia.

INRA. 2015. Anuario 2015. La Paz: Instituto Nacional de Reforma Agraria. 
Laats, Henkjan, Mirna Liz Inturias, and Clemente Caymani. 2012. Megaobras En Madidi Y Pilón Lajas. Hacia Una Transformación de Los Conflictos. La Paz: Embajada Real de Dinamarca, Fundación PIEB.

Law No. 300. 2012. Government of the Plurinational State of Bolivia.

http://comunicacion.presidencia.gob.bo/docprensa/pdf/20121015-11-53-28.pdf.

Law No. 1333. 1992. Government of the Republic of Bolivia. http://www.lexivox.org/norms/BO-L1333.xhtml.

Law No. 1715. 1996. Government of the Republic of Bolivia. https://bolivia.infoleyes.com/norma/1274/ley-del-servicio-nacional-de-reforma-agraria1715 .

Law No. 3545. 2006. Government of the Plurinational State of Bolivia.

http://www.inra.gob.bo/InraPb/upload/DBL-51-8895999.pdf;jsessionid=AAEA224B0C78CB8B3753C51BB347E84F.

Márquez Guerra, José Francisco. 2015. L'agency de la route Yucumo-Rurrenabaque entre développement, conservation et autonomie indigène: une étude de cas dans l'Amazonie Bolivienne. Desenvolvimento e Meio Ambiente 33:177-91.

Martinez-Rodriguez, Maria-Ruth. 2009. "Ethnobotanical Knowledge Acquisition Among Tsimane' Children in the Bolivian Amazon." PhD, University of Georgia.

McLaughlin, Caroline M. 2011. "People Living in Protected Areas. A Comparative Study of the Social Impacts of Conservation in Latin America's Mamirauá Sustainable Development Reserve and Ría Celestún Biosphere Reserve." Unpuplished Master's dissertation, American University United Nations' University for Peace.

Minter, Tessa, Jan van der Ploaeg, Maria Pedrablanca, Terry Sunderland, and Gerard A. Persoon. 2014. Limits to Indigenous Participation: The Agta and the Northern Sierra Madre Natural Park, the Philippines. Human Ecology 42:769-78.

Muller, Samantha. 2014. Co-motion: Making space to care for country. Geoforum 54:132-41.

Nadasdy, P. 2005. The Anti-Politics of TEK: The Institutionalization if Co-Management Discourse and Practice. Anthropologica 47 (2):215-32.

Pauquet, Stéphane. 2005. Diagnosis of the Pilon Lajas Biosphere Reserve and Communal Lands. In ParksWatch Park Profile Series. La Paz.

Paz Ballivián, Danilo. 2015. "Nacionalismo O Coloniaje En El Desarrollo Agrícola." La Razón, May 24. http://la-razon.com/suplementos/animal politico/Nacionalismo-coloniaje-desarrolloagricola $02276172430 . \mathrm{html}$.

Pimbert, Michel, and Jules Pretty. 1997. Parks, People and Professionals. Putting "Participation" into Protected Area Management. In Pimbert Krishna Ghimire, Michel, ed., Social Change and Conservation. Environmental Politics and Impacts of National Parks and Protected Areas, 297-330. London: Earthscan.

Rathwell, Kaitlyn Joanna, Derek Armitage, and Fikret Berkes. 2015. Bridging knowledge systems to enhance governance of the environmental commons: A typology of settings. International Journal of the Commons 9 (2):851-80.

Reyes-García, Victoria, Jaime Paneque-Gálvez, Patrick Bottazzi, Ana C. Luz, Maximilien Gueze, Manuel J. Macía, Martí Orta-Martínez, and Pablo Pacheco. 2014. Indigenous land reconfiguration and fragmented institutions: A historical political ecology of Tsimane' lands (Bolivian Amazon). Journal of Rural Studies 34:282-91.

Ringhofer, Lisa. 2010. Fishing, Foraging and Farming in the Bolivian Amazon. On a Local Society in Transition. Dordrecht Heidelberg London New York: Springer.

Sanchez-Lopez, Daniela. 2015. Reshaping notions of citizenship. The TIPNIS Indigenous Movement in Bolivia. Development Studies Research 2 (1):20-32.

Schavelzon, Salvador. 2012. El nacimiento del Estado Plurinacional de Bolivia. Etnografía de una Asamblea Constituyente. La Paz: CLACSO, Plural Editores, CEJIS, IWGIA. 
SERNAP, Servicio Nacional de Areas Protegidas, and Concejo Regional Tsimane Mosetene CRTM. 2009. Plan de Manejo y Plan de Vida de la Reserva de la Biosfera y Tierra Comunitaria de Origen Pilón Lajas 2007-2017.

"Sobre Normativa Agropecuaria." 2015. La Razón, August 30. http://www.larazon.com/suplementos/la gaceta juridica/normativa-agropecuaria-editorialgaceta 0 2334366681.html.

Supreme Decree No. 727. 2010. Government of the Plurinational State of Bolivia. http://www.lexivox.org/norms/BO-DS-N727.xhtml.

Supreme Decree No. 2195. 2014. Government of the Plurinational State of Bolivia. http://www.lexivox.org/norms/BO-DS-N2195.xhtml.

Supreme Decree No. 2298. 2015. Government of the Plurinational State of Bolivia. http://www.lexivox.org/norms/BO-DS-N2298.xhtml.

Supreme Decree No. 2366. 2015. Government of the Plurinational State of Bolivia. http://www.lexivox.org/norms/BO-DS-N2366.xhtml.

Supreme Decree No. 23110. 1992. Government of the Republic of Bolivia. http://www.lexivox.org/norms/BO-DS-23110.xhtml.

Supreme Decree No. 24781. 1997. Government of the Republic of Bolivia. http://www.lexivox.org/norms/BO-DS-24781.xhtml

Supreme Decree No. 25158. 1998. Government of the Republic of Bolivia. http://www.lexivox.org/norms/BO-DS-25158.pdf

Supreme Decree No. 29191. 2007. Government of the Republic of Bolivia. http://www.lexivox.org/norms/BO-DS-29191.xhtml.

Surkin, Jordi, Juan Carlos Miranda, and Edwin Miro. 2010. Corresponsabilidad en la gestión de los recursos naturales en Pilón Lajas.

Tengö, Maria, Eduardo S. Brondizio, Thomas Elmqvist, Pernilla Malmer, and Marja Spierenburg. 2014. Connecting Diverse Knowledge Systems for Enhanced Ecosystem Governance: The Multiple Evidence Base Approach. AMBIO 43 (5):579-91.

Tockman, Jason, and John Cameron. 2014. Indigenous Autonomy and the Contradictions of Plurinationalism in Bolivia. Latin American Politics and Society 56 (3):46-69.

Umans, Laurent, and Alberto Arce. 2014. Fixing rural development cooperation? Not in situations involving blurring and fluidity. Journal of Rural Studies 34:337-44.

UNDP. 2012. Tsimané Mosetene Regional Council, Pilon Lajas, Bolivia. Equator Initiative Case Study Series. New York.

UNESCO. 1974. Programme on Man and the Biopshere (MAB) Task Force on: Criteria and guidelines for the choice and establishement of biosphere reserves. Final Report. Paris: UNESCO and UNEP.

Van Cott, Donna Lee. 2001. Explaining Ethnic Autonomy Regimes in Latin America. Studies in Comparative International Development 35 (4):30-58.

von Stosch, Kristina. 2010. "Hochland- und Tieflandindigene im Konflikt : Land und RessourcenNutzung in Alto Beni / Bolivien."

West, Paige, James Igoe, and Dan Brockington. 2006. Parks and Peoples: The Social Impact of Protected Areas. Annual Review Of Anthropology 35:251-77.

Zimmerer, K. S. 2015. Environmental governance through "Speaking Like an Indigenous State" and respatializing resources: Ethical livelihoods concepts in Bolivia as versatility or verisimilitude? Geoforum 64:314-24.

Zycherman, Ariela. 2013. "The Changing Value of Food. Localizing Modernity among the Tsimané Indians of Lowland Bolivia."Ph.D. dissertation, Columbia University. 